\title{
PRAGMATIC MEANINGS OF JAVANESE PHATIC MARKER 'SAMPUN': CULTURE-SPECIFIC PRAGMATIC PERSPECTIVE
}

\author{
R. Kunjana Rahardi \\ Master Program of Indonesian Language Education, \\ Faculty of Teachers' Training and Education, Sanata Dharma University Yogyakarta, Indonesia \\ Jalan Affandi, Gejayan, Catur Tunggal, Depok, Sleman, Yogyakarta 55281, Indonesia \\ Corresponding Author: kunjana@usd.ac.id
}

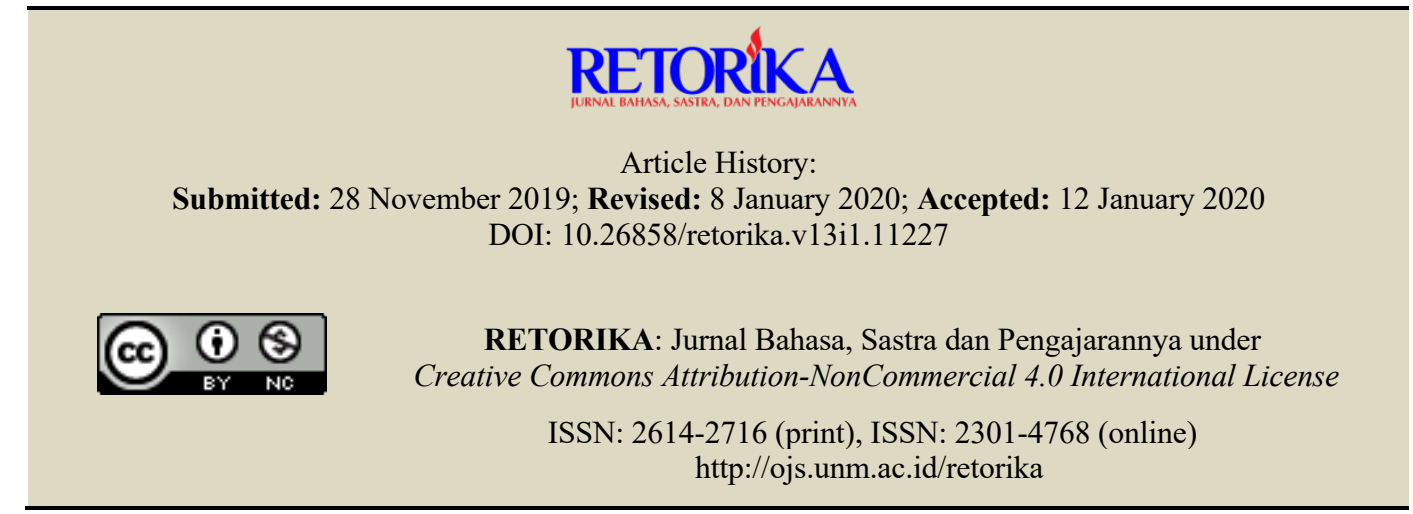

\begin{abstract}
The Javanese phatic marker 'sampun' draws several interpretations to researchers. The variety of interpretation poses communication problems in the daily communication, especially for people that do not fully understand the Javanese language and culture. The data consisted of excerpts of utterances transcribed from the recording tape of full conversations containing the phatic 'sampun' as discourse markers. The data gathering methods employed in this research were observation and speaking methods. Both types of data gathering methods employed the basic and advanced techniques in their elaboration. After being classified and typified properly, the data was analyzed using the distributional analysis method and pragmatic identity method commonly used in a linguistic research. The research showed the following results namely (1) the cultural context to emphasize intention, (2) the cultural context to emphasize the speaker's hope and expectation, (3) the cultural context to emphasize the speaker's intention to convince the hearer, (4) the cultural context to emphasize the speaker's intention to question the hearer, (5) the cultural context to emphasize the speaker's intention to agree, (6) the cultural context to convey disappointment, (7) the cultural context to emphasize the speaker's inconvenience.
\end{abstract}

Keywords: phatic word 'sampun'; cultural marker; pragmatic meanings

Research on the phatic word 'sampun' in the Javanese language from the pragmatic perspective has not been done by linguists. The phatic word 'sampun' is widely used by the speech community in a daily conversation. The Javanese community and culture rich in kesamudanan (façade) dimension is one of the factors why the linguistic forms in the Javanese language are loaded with such indirectness and circuitousness (Sarsito, 2006); (Herliana, 2015). Pragmatic studies have explained that indirectness is one of the manifestations of politeness. Likewise, façade is the manifestation of linguistic politeness in the Javanese speech community 
(R. Kunjana Rahardi, 2017b). Thus, façade can be interpreted and understood as such, namely as a manifestation of linguistic politeness in the Javanese community (R. Kunjana Rahardi, 2018b). When someone has just bought a car, for instance, a neighbor would come by to praise the car by saying 'enggal njih montore' or 'look at this new car.' The word 'montor' is used to refer to both 'motorbike' and 'car' spoken by people in the rural area.

To respond to this praise, the car owner would say 'mboten...wong namung grobak kok niki' or 'no, it's just a junk.' Obviously, his utterance obscures, denies, and negates the fact that he has just bought a new car. He avoids calling the new car as a 'car' or 'montor' as referred by the neighbor. Instead, he refers to his car as a 'gerobak' or 'junk'. Referring to his car as 'junk' is obviously a form of a façade. Façade is expressed in the name of humility by referring to a 'car', no matter how expensive it is, as a 'junk' or literally 'horse-drawn wagon'. The word is used to refer to the traditional means of transportation drawn by two horses. During the harvest of cassava and yams, a farmer in the village may say 'these are just tiny cassava and yams,' to respond to his neighbour's praise over his crops.

The use of the expression 'just tiny' to negate the fact that the size of the crops is big, even as big as a man's arm to say the least, is the manifestation of indirectness or circuitousness. The form 'they're just tiny' to negate the fact that they are actually 'as big as a strong man's arm' is an example of indirectness (SpencerOatey \& Jiang, 2003). In other words, the manifestation of the façade culture appears in the use of such linguistic form. The form 'sampun' or 'sampun, sampun' in the Javanese speech community does not always mean 'that's enough' or 'that's enough, no more, please.' On the contrary, the meaning of the expression 'sampun' is actually 'yes, I will.' The pragmatic meaning of the linguistic form of the phatic 'sampun' is the focal point of this short article. Through this study, it is expected that the pragmatic meaning or intention of the linguistic form will be revealed and described comprehensively, so that good communication will be built to avoid misunderstanding.

The theories underlying this research is a pragmatic theory which is commonly understood as the context-bound, instead of context-free linguistic study. The pragmatic study focuses on the pragmatic meaning, speaker's meaning, while the linguistic study focuses on the linguistic meaning, i.e. semantic meaning (Mey, Brown, \& Mey, 2006). Semantic meaning is context-free, unless the context is intralinguistic or commonly referred to as co-text.

Speaker's meaning is context-bound, especially the extralinguistic context or commonly referred to as context itself (R. Kunjana Rahardi, $2017 \mathrm{c}$ ). In relation to pragmatics mentioned previously, it must be affirmed that pragmatics is used as the frame of reference and the analytical tool used in this research is pragmatics in a specific sense, instead of pragmatics in a general sense. It is called a specific dimension because the object of research is the Javanese culture. Therefore, it can be said that pragmatics mentioned previously is culture-specific. In terms of culture-specific pragmatics, Leech has defined sociopragmatics. In this term, it is implied that universally-based pragmatics is applied specifically in a certain culture (Cogo \& House, 2017); (Mills, 2009).

It can be affirmed that the social, societal, and cultural dimensions of pragmatics are interpreted specifically in the field referred to by this expert as sociopragmatics. Furthermore, it is also necessary to emphasize that sociopragmatics has a counterpart, namely pragmalinguistics. Pragmatics is said to be a context-bound linguistic study, and the context in question is an extralingual context, which does not always apply this way in practice. Pragmatics is not always an extralingual context, but it is also closely related to an intralingual context (J. Chen, 2017). For example, the intonation, duration, and volume of the speech proved to be very decisive in determining the speaker's meaning in the pragmatic study. Thus, it must be emphasized that linguistic aspects can also determine the speaker's meaning in pragmatic studies (Rashid, Ismail, Ismail, \& Mamat, 2017).

However, the previously-mentioned fact is often not acknowledged by pragmatic experts in their books. This research also ignores internal linguistic dimensions in interpreting the meaning of an utterance. In other words, only extralinguistic contexts will be used to determine the meaning of an utterance in interpreting the Javanese phatic 'sampun'. Another theory underlying 
this research is the importance of external linguistic contexts or referred to as extralinguistic contexts (Renkema, 2005).

Rahardi mentioned in his latest book that extralinguistic context can at least be divided into four types, namely social, societal, cultural, and situational contexts. The social context is closely related to horizontal dimensions of society (R. Kunjana Rahardi, 2018a); (R. Wodak \& Meyer, 2016). For instance, the relationship among farmers, traders, students, and lecturers are horizontal relationship. The utterances they convey in communicating with each other can be understood by means of social contexts. In contrast, the communication between lecturer and students, housemaids and hosts, employees and leaders is vertical in nature. Despite their close relationship, employees and chief executive officers must have a vertical relationship.

Likewise, the relationship between housemaids and their hosts is definitely vertical (Carston, 2005); (Chen \& Yang, 2010). The linguistic forms being conveyed will be interpreted appropriately when the societal nature of the extralinguistic context is applied (Mey et al., 2006). The relationship distance between the two parties causes the vertical relationship. In the past, even today, in the palace domain, the relationship between 'courtiers' and 'princes' was always vertical. The utterances spoken by both parties can be interpreted correctly only if the societal dimension is being applied.

The next type of context is the cultural context. The cultural context is closely connected with the culture of the speech community (Halliday, 1978). Therefore, the background of a particular cultural context is different from the background of other cultural contexts. Understanding the speaker's meaning in one culture is different from interpreting utterances in other languages. The form 'yes', for the Javanese people, may be interpreted as 'yes' or agreement and 'no' as disagreement. On the other hand, in the Javanese culture, the form 'no' can actually mean 'agreement'. So, the cultural context plays a very important role in determining the speaker's meaning and the meaning of an utterance (Wharton, 2009).

In a different culture, Batak for instance, the linguistic form 'yes' is not interpreted as 'disagreement'. Likewise, in the Minang language and culture, the linguistic form 'no' does not mean 'agreement'. Therefore, the cultural con- text really determines the meaning of an utterance and the speaker's meaning. Intercultural understanding of the speaker's meanings and intentions and cross-cultural understanding are prerequisite for the establishment of good communication. Furthermore, the most recent type of extralingual contexts is the situational context (Culpeper, 2010).

The situational context was originally introduced by Malinowski, who studied the life of the Trobriand people on the Pacific islands in 1923 (Geertz, 1957). The term 'situational context' emerged from his experience as a translator of the languages of the Trobriand people in his anthropological work (Robbins, 2008). In addition to creating the term 'situational context', this researcher played a major role in introducing the term 'phatic', which will be discussed separately in this paper.

Furthermore, the situational context is described by Leech, who confirms that the situational context of an utterance includes (a) the speaker, (b) the hearer, (c) the context of an utterance, (d) purpose of an utterance, (e) speech act, (f ) verbal action ( $\mathrm{Yu}, 2011)$. Thus, in Leech's view, the meaning of an utterance must be observed by interrelating it with the aspects of situational contexts. Interpreting the meaning of an utterance without regarding the aspects of situational contexts of an utterance will not generate an optimal interpretation. Even worse, the interpretation may be incorrect and inaccurate (R. Kunjana Rahardi, 2017a).

Thus, extralinguistic contexts play such an important role in interpreting the speaker's meaning that contexts must be understood accurately by speakers and hearers to establish successful communication. The third theory to understand the meaning of the phatic 'sampun' is the theory of phatic functions. Previously, it was mentioned that phatic communion was first introduced by a well-known anthropologist, Malinowski in 1923. Phatic communion in Malinowski's perspective refers to utterances which do not contain any meaning (Yu, 2011). It means that phatic communion does not communicate any information. If communication is interpreted as conveying meaning or getting the meaning across, phatic communion does not convey significant information in communication.

Furthermore, Roman Jakobson does not exactly explain phatic communion clearly. In his perspective, phatic communion refers to utter- 
ances that do not have a special meaning, which functions to facilitate communication and interaction (Scollon \& Scollon, 2001); (Palacio \& Gustilo, 2016). Sometimes communication between speakers and the hearers may not be smooth, or even hampered because of the absence of communication fillers. Therefore, in Indonesian there are linguistic forms that cannot be categorized in the word classes, although these forms are actually used in real conversation (Kridalaksana, 1979). The fillers ' $u m$... um ..'or 'uhuk-uhuk', or 'ahh..ahh' do not have semantic meaning, and they are not classified in any of the word classes.

Leech proposes a somewhat different definition from the ones proposed by his predecessors. In Leech's point of view, phatic function serves to break the silence. Hence, the phatic function can manifest in linguistic forms devoid of meaning, which functions to establish communication, initiate communication, and sustain communication (Goddard, 2004); (SpencerOatey \& Jiang, 2003). For example, when you are traveling on a train on a long distance ride, you would say 'It's so hot here. The AC does not seem to work' to a passenger next to you. He would respond to your statement and conversation would take place all the way to Jakarta. Thus, it can be said that linguistic forms are manifestations of phatic functions because the main purpose of phatic functions is to break the silence.

Thanks to the phatic functions, the communication can be established smoothly. In Leech's terms, such forms are fillers, whereas Roman Jakobson referred to it as communication icebreaker (Chen \& Yang, 2010), (Salehuddin, Winskel, \& Maros, 2011). The three theories presented above functioned as a framework of reference and as an analytical tool to carry out this research. With all the theories described above, the problems associated with the phatic 'sampun' will be solved, and the results will be very useful for developing linguistics, especially those related with pragmatics.

\section{METHOD}

The pragmatic study of the Javanese phatic word 'sampun' is qualitative. That is, there will be no quantification of numbers in the research on the meaning of the Javanese phatic word 'sampun'. The source of the locative data in this study was the Javanese speakers who speak Javanese on a daily basis. Similarly, when they speak Indonesian, these language aspects cannot be eliminated because they are deeply ingrained in these people. In other words, their Javanese lingual intuition has been very strongly embedded because they are native speakers of the language being studied.

The second locational data source was the author himself. Being a Javanese himself, he has a very close linguistic distance with the Javanese language. The substantive data sources are speech excerpts obtained from locational data sources (Sudaryanto, 2015), which contain the use of the Javanese phatic 'sampun'. The research data is in the form of speech excerpts from substantive data sources, in which there is the use of phatic word 'sampun'. The data was collected by applying the observation method and the speaking method as commonly used in the linguistic research. Both types of methods are applied with the basic and advanced techniques.

The objects being observed are the excerpts containing utterances obtained from the locational data source. Interviews were carried out to confirm the truth about some facts during the observation on the phatic word 'sampun'. The analytical method used in this study was the distribution analysis method and identity method (R. Kunjana Rahardi, 2017b). The distributional analysis method is used to solve problems related to linguistic dimensions, while the identity method is used to solve the problems related to the pragmatic dimensions of the Javanese phatic word 'sampun'.

\section{FINDINGS AND DISCUSSION}

\section{Findings}

In its existence, the Indonesian language is influenced by many regional languages as supporting pillars, and Javanese is one of the strongest supporting languages for the existence of the national language. The fact that local languages and the national language support each other contributes greatly to the life, development, and the process of ennobling these languages. Therefore, it can be affirmed that the study of the Javanese phatic word 'sampun' in 
the context of developing and positioning the Javanese language also indirectly contributes to the development and ennoblement of the Indonesian language. In the following section, the discussion of each data on the use of the phatic 'sampun' will be presented one by one.

\section{The Cultural Context to Emphasize Intention}

One of the extralinguistic contexts is a cultural context. Different cultural contexts manifest differently, depending on the people who share these cultural values. The Javanese society rich in cultural values shares various cultural traditional values (Kotthoff, 2005); (Braten, 2001). These various cultural values have potentials to create misunderstandings among those who are newcomers to the culture. The following excerpt shows that the function of the context is to emphasize intention.

Excerpt of Utterance 1:

A. Ayo ditambah sedikit lagi segane. Ben ndang gedhe, thole!

B: Wah...sampun saestu tuwuk Mbah. Mboten miyat weteng kula hehe.

A: Ora popo! Ayo tak jupukke lawuhe ya! Nambah sithik!

B: Matur nuwun sanget Mbah.

A: Come on, have more rice. It will make you grow up strong, son!

B: Oh..., no more, Grandpa. Seriously. I am really full. My stomach cannot hold it anymore. Hehe.

A: No problem! Here, let me get the side dish for you! Just a little bit more!

B: Thank you very much, Grandpa.

Context:

A teenage boy visited his grandfather's house in the village. In a relaxed atmosphere, the grandson was having dinner with his grandfather, who ordered him to add more rice to which he declined. However, when the grandfather helped him with the second filling, the grandson eventually accepted.

In the above excerpt, the phatic form 'sampun' was used as in 'Wah...sampun saestu tuwuk Mbah' or 'Oh...no more, Grandpa,' at first was intended to show the pragmatic meaning of the word 'sampun.' The use of this form is reinforced by the word that follows it, namely the word 'saestu' which means 'seriously'. Howev- er, when the speaker was encouraged to add more rice by the grandfather, the speaker finally accepted the offer. What's more, when the grandfather said he would get his side dish by saying 'Ora popo! Ayo tak jupukke lawuhe ya! Nambah sithik!' eventually, the grandson agreed to accept the additional side dish. He confirmed his agreement by saying 'Matur nuwun sanget, Mbah!' or 'thank you very much, Grandpa.'

Thus it can be affirmed that the use of the phatic word 'sampun' above by the grandson changed in meaning between the first and the second 'sampun.'At first, the phatic word 'sampun' was actually used to reject the offer. However, toward the end, the interpretation of the word 'sampun' changed to phatic function to express pretense. The fact of using the utterance in this way can occur to a culture-specific society. The same word may have various pragmatic meanings depending on the context. The context can be social and societal, but it can also be cultural and situational (Mey, 2006), (de Rycker \& Ponnudurai, 2011). In connection with the utterance above, the dominant cultural context determined the meaning. People who come from different cultures might not understand the Javanese phatic word 'sampun' straight away.

\section{The Cultural Context to Emphasize the Spea- ker's Hope and Expectation}

The repetitive forms of a language is commonly used to emphasize something. In the Indonesian language, the word 'jangan' or 'don't' can be stated repetitively, as in 'jangan...jangan...jangan.' Such a linguistic form shows that the prohibition using the word 'don't' is expressed seriously (R. Kunjana Rahardi, 2010). Similarly, the Javanese word 'sampun' as shown in the following excerpt emphasizes the hope or expectation.

\footnotetext{
Excerpt of Utterance 2:

A:Wong kok senenge ngeyel terus! Dikandani malah njawab! Ra bener kuwi. Iso tak tendhang tenan tho mengko. Ayo meneng!

B: Yo wis tho Mas! Sampun.....sampun....sampun. Sing uwis yo uwis, rasah diterus-teruske le dukaduka. Aku wis rumungso salah. Ora tak baleni.

A: Yo ngono kuwi senengmu! Yo uwis....yo uwis. Pancen ora nggenah!
} 


\section{B: Iyo Mas. Aku wis ra arep mbaleni.}

A: Why are you so disagreeable? Don't talk back at me! It's not polite. I could kick you out of here. Shut up!

B: Please, let it go, Mas! Enough... That's it. That's enough. What's done is done. Quit being angry about it. I said it was my fault. I will never do that again.

A: Well...that sounds like you, alright! Enough...enough....Enough my ass!

B: I know, Mas. I will never do that again.

Context:

The conversation took place in a family between a husband and a wife who were arguing. The wife tried to dissipate the husband's anger, but the husband could not control his anger. The anger was triggered when the wife mistakably bought a wrong item, which infuriated her husband.

The excerpt of utterance 3 above occurred in a household, where the husband scolded his wife. The husband was infuriated because his wife kept talking back at him when he reprimanded him, an act which was defined as 'ngeyel' or 'nagging retort'. Being irritated by his wife's act of insolence, the husband threatened her of throwing her out unless she stopped talking. Fearing the threat, the wife relented and stopped talking. The following excerpt confirms this, 'Yo wis tho Mas! Sampun...sampun...sampun. Sing uwis yo uwis, rasah diterus-teruske le duka-duka. Aku wis rumungso salah. Ora tak baleni.' (Please, let it go, Mas! Enough...That's it. That's enough. What's done is done. Quit being angry about it. I said it was my fault. I will never do that again). The form 'sampun' 'which has the same meaning as 'Enough....that's it. That's enough,' is stated repetitively to express her hope that her husband will stop being angry.

\section{The Cultural Context to Emphasize the Spea- ker's Intention to Convince the Hearer}

The pragmatic meaning 'assuring' is conveyed by the speaker to the hearer in an utterance which commonly happens in a daily conversation. The speaker's intention to 'assure or convince' is inferred from the linguistic form of the utterance and from the context surrounding the utterance. In the following excerpt of utter- ance, the cultural context determines the speaker's intention to assure or convince the hearer. The cultural context appears in the conversation between a father and his daughter from the Javanese cultural background (Lukens-bull, 1995).

\section{Excerpt of Utterance 3:}

A: Bagaimana, sudah diserahkan belum rancangan proposalmu ke pembimbingmu, Nok!

B: Njih sampun tho Pak. Tadi malam kan saya lembur ngetik proposal sampai tengahj malam.

A: Yo wis apik! Ojo suwe-suwe sowan maneh ke dosenmu ya Nduk!

A: Tentu Pak. Kula rajin kok ke kampus, sekalian ngobrol kalih konco-konco kula.

A: Well, have you submitted your thesis proposal to your advisor, honey?

B: Well, of course I did, Father. Last night, I stayed overnight typing the proposal until after midnight.

A: That's great! Don't take too long before you see your advisor, honey!

A: Certainly, Father. I go to campus everyday, and I can hang out with my friends there, too.

\section{Context:}

The conversation took place in the family living room. A father spoke to his daughter about her thesis writing process. The father paid attention to his daughter's progress of study when he asked questions about the development of her proposal writing. The conversation took place in a relaxed and familial manner.

The speaker's intention to assure the hearer using the phatic 'sampun' is shown in the utterance 'Njih sampun tho Pak. Tadi malam kan saya lembur ngetik proposal sampai tengahj malam'. It was clear that the speaker's intention is to assure the hearer. The linguistic form 'njih sampun' or 'yes, of course I did' is intended to assure or convince the hearer. The hearer is the father who keeps asking about his daughter's progress in thesis writing and consultation with her thesis supervisor.

The following excerpt clarifies the point, 'Yo wis apik! Ojo suwe-suwe sowan maneh ke dosenmu ya Nduk!' or That's great! Don't take too long before you see your advisor, honey! This typically wise parental advice is commonly 
given by the parent to the child in the Javanese family (Anderson, 1972). Customarily, a child must act politely and respect his/her parents as shown in the following excerpt: 'Tentu Pak. Kula rajin kok ke kampus, sekalian ngobrol kalih konco-konco kula,' or 'Certainly, Father. I go to campus everyday, and I can hang out with my friends there, too.'

\section{The Cultural Context to Emphasize the Spea- ker's Intention to Question the Hearer}

The pragmatic meaning of the phatic word 'sampun' gets clearer depending on the context surrounding the utterance. Children sometime lead their parents into thinking they are obedient when they are asked to take a nap. They prefer to play with their gadget than taking a nap. Afterwards, when confirmed by parents whether they are taking a nap, the child tends to lie by saying 'sampun' as shown in Excerpt 4.

\section{Excerpt of Utterance 4:}

A: Kula sampun tilem wau Bu. Sak niki badhe pados jajanan teng njawi.

B: Sampun? Sampun, sampun apa? Wong aku ngerti kowe dolanan HP kok.

A: Estu Ibu. Kula mboten ngantuk sakniki.

B: Yo wis kana, ojo suwe-suwe. Wong disuruh tidur siang kok malah jajan.

A: Njih Bu!

A: I have taken a nap, Mom. Now, I'm heading out to get something to eat.

B: Have you? Have you? Have you really taken a nap? Because I know for sure that you were just playing with your phone.

A: Really, Mom. I am not sleepy now.

B: Well, in that case, go on now. But don't take too long. Why are you going out instead of taking a nap?

A: Okay, Mom.

Context:

This conversation took place in the family domain between a teenage boy and his mother. The boy was asked to take a nap. Instead of sleeping, the boy was playing with his phone while pretending to sleep on the bed to fool his mother. When the boy told his mother that he wanted to go out to get something to eat, he lied to his mother about having taken a nap. His mother scolded him for lying.
The linguistic form 'sampun' conveyed by the boy is classified as phatic. The fact is that the boy did not sleep at all because he was playing with his phone. The phatic form appears in the utterance: 'Kula sampun tilem wau Bu.' The following utterance: 'Sak niki badhe pados jajanan teng njawi' further affirms that the form 'sampun' does not communicate the information of 'having taken a nap.' The speaker wanted to get out of the house so his mother would not find out that he did not sleep. In the following excerpt, his mother expressed her distrust by questioning his statement 'sampun'.

It means that his mother did not really believe that her son had taken a nap. The questioning is affirmed by repeating the word 'sampun' three times to show her disbelief, as in 'Sampun? Sampun, sampun apa?' or 'Have you? Have you? Have you really taken a nap? Because I know for sure that you were just playing with your phone.' Thus, it can be confirmed that the use of the repeated form 'sampun' as in the excerpt is to emphasize the speaker's intention to question the teenage son. Thus, the pragmatic meaning of the word 'sampun' uttered by the speaker (the teenage boy) and the hearer (the mother) has two different meanings.

The difference is determined by the situational context, which of course is strongly determined by the culture. In other words, the situational context cannot be separated from its cultural context. Likewise, the social and societal contexts (Mey, 2002) obviously cannot be separated from its cultural context.

\section{The Cultural Context to Emphasize the Spea- ker's Intention to Agree}

The following excerpt of utterance ocurred in the market where people may bargain prices. In the following excerpt, the bargain was between the buyer and the seller. In the conversation, the word 'sampun' was uttered by the buyer, as in 'Njih sampun. Ditimbang njih, Mbok. Pas sekilo mawon njih,' or 'Well, alright then. Please use the measurement. I just need one kilo.' The purpose of using the phatic 'sampun' is to express agreement. The statement of agreement is shown in the phrase 'njih sampun' which means the conclusion of the bargaining process between the seller and the buyer. The complete conversation is shown in the following excerpt. 
Excerpt of Utterance 5:

A: Mbok, niki pinten regine? Kula tumbas sekilo mawon. Pareng tho?

$B$ : Monggo Bu, wah sakniki mindhak e regine. Setunggal kilo sampun 50 ewu.

A: Lha kok dadi larang. Pripun 40 ewu njih. Mung nggoi campuran masak dhewe teng nggriyo kok.

B: Dereng saged, Bu. Yen kersa 45 ewu, sumonggo.

A: Njih sampun. Ditimbang njih, Mbok. Pas sekilo mawon njih.

A: Mbok, how much is this? I'd like to buy a kilo of this. May I?

B: Yes, please, Ma'am. But unfortunately, the price has increased, Ma'am. It's 50,000 a kilo now.

A: Wow, it's getting expensive by day. How about 40,000 a kilo? I would need that to cook for my family.

B: I'm sorry, Ma'am. I can't do that. How about 45,000 a kilo? It's yours if you want.

A: Alright, then. Please use the measurement. I just need one kilo.

(The conversation took place in a vegetable stall where they sell beef, chicken meat, and vegetables. A buyer and a seller were bargaining prices of the meat and vegetables. The conversation took place in a relaxed manner despite the crowd and noises).

The use of the phatic 'sampun' in the excerpt confirms that the word 'sampun' in the Javanese language is used to express agreement. The use of the cultural context that surrounds the utterance further emphasizes the speaker's intention to agree with the hearer. Thus, it can be affirmed that the cultural context cannot be ignored in determining the speaker's meaning. The social and societal contexts are not enough to determine the pragmatic meaning of a speaker's utterance. (Waugh et al., 2016). Likewise, the situational context is very limited to determine the pragmatic meaning of a speaker's utterance. In other words, the cultural context dominantly determines the speaker's pragmatic meaning especially in a culture-specific society.

\section{The Cultural Context to Convey Disappoint- ment}

The phatic form 'sampun' can be used to convey disappointment. In the following utter- ance, the word 'sampun' as in 'Wow! nggih sampun! Wis kebanjur di-klik dan dikirim yo wis bablas,'obviously conveys disappointment. Even without linking it to the context, it is very clear that the utterance above conveys the speaker's disappointment. Culturally, the form 'wow...njih sampun' contains the intention of regretting that something has happened. Thus, the form ' $y a$ sudah' implies the intention of 'unfortunately something has happened.' In the Javanese language, the form of 'njih sampun' or 'alright then' actually implies the pragmatic meaning of regretting something that happened. Readers may look closely at the following excerpt of utterance to get a clearer example of an utterance that conveys disappointment (Kramsch, 2002).

\section{Excerpt of Utterance 6:}

A: Wah kula lepat e Pak. Terlanjur kula kintun jebule taksih salah.

B: Wow...nggih sampun! Wis kebanjur diklik dan dikirim yo wis bablas.

A: Nyuwun ngapunten njih Pak. Kula rada kesusu-susu wau.

B: Yo kuwi. Wis kebanjur yo wis. Ra popo.

A: I think I made a mistake, Sir. I have already sent it before I knew it was wrong.

B: Well, there is nothing we can do. If you have clicked the 'send' button, it's gone already.

A: I'm sorry, Sir. I was in a hurry.

B: I've told you not to. But it's done. It does not matter.

\section{Context:}

The conversation took place between an office manager and his secretariat staff. The conversation took place when the secretary mistakenly sent the document which still contained errors. Being disappointed, the office manager spoke to the staff. The conversation was a bit awkward and uncomfortable due to the errors.

The utterance between an office manager and a secretarial staff in the excerpt above confirms that the purpose of an utterance cannot be separated from the context of the utterance. Contexts of an utterance can take various forms, namely social, societal, situational, and cultural contexts. The statement 'Nggih Sampun' was uttered by a Javanese office manager.

The expression was conveyed to the hearer who also had a Javanese cultural background. 
The role of the situational context is seen from the atmosphere when the conversation took place. It was a bit tense and awkward because the employee felt that he had done something wrong. The office manager also seemed to be tense because in fact he felt disappointed with the employee and the mistake he had caused. The horizontal relationship between the interlocutors as the social context cannot be seen because both parties are actually different in terms of social status. Thus it can be affirmed that the societal context plays an important role to determine the meaning of the utterance in the text above.

\section{The Cultural Context to Emphasize the Spea- ker's Inconvenience}

In the following excerpt, the expression of inconvenience emerged when a junior lecturer wanted to help carrying the senior lecturer's stuff. The phatic expression 'sampun' which was repeated three times was intended to convey the inconvenience for having the junior lecturer carry his stuff. The repetition of the word 'sampun' emphasizes his rejection for being helped. The following utterance can be scrutinized carefully to get a clear depiction of how the intention to show inconvenience using the phatic 'sampun' is expressed.

Excerpt of Utterance 7:

A: Sini saya bantu bawakan Pak. Kados awrat sanget!

B: Sampun, sampun, sampun! Kula piyambak saget kok.

A: Mboten napa-napa, mriki kula bopongke!

B: Yo wis....matur nuwun sanget njih. Penjenengan kuwi pancen enthengan kok.

A: Here! Let me help you carry the stuff, Sir. It looks so heavy!

B: No, no, no! It's fine. I can carry them myself.

A: It's okay, really. Let me help you carry them!

B: Well, thank you. You are very helpful.

\section{Context:}

The conversation took place in the campus hall between a senior lecturer and a junior lecturer. They walked to the campus parking lot. The senior lecturer carried so many stuffs and he seemed to be have difficulties carrying all his stuffs. The junior lecturer offered to help and carry his stuff.

The phatic word 'sampun' in the excerpt above was used to express inconvenience. Disregarding the contexts, it is enough to see the pragmatic meaning of the phatic word 'sampun' in the utterance above. The repetition of the word 'sampun' into 'sampun, sampun, sampun. Kula piyambak saget kok,' clarifies the intention of inconvenience. Therefore, the cultural context is used to emphasize the intention of the word 'sampun' to express inconvenience. The utterance took place in a relaxed atmosphere. The emerging social context was the horizontal dimensions because both lecturers are colleagues (Wodak, 2007).

\section{Discussion}

Based on the result of the above analysis, it must be emphasized that the invention of seven communicative functions of the cultural context (Armstrong \& Ferguson, 2010) attaching to Javenese phatic word 'sampun' proves that pragmatic researches applying specific-culture perspective will renew the already-established emerging concepts of cultural context (R.K. Rahardi, 2018), (Rashid et al., 2017). The renowed concepts of cultural context was formerly asserted by Halliday, and therefore his assertion is now revised through this invention (Wiley, 1983), (Halliday, 2015). Those cultural context functions are consecutively depicted as follows. (1) The cultural context to emphasize intention; (2) The cultural context to emphasize the speaker's hope and expectation; (3) The cultural context to emphasize the speaker's intention to convince the hearer; (4) The cultural context to emphasize the speaker's intention to question the hearer; (5) The cultural context to emphasize the speaker's intention to agree; (6) The cultural con-text to convey disappointment; (7) The cultural context to emphasize the speaker's inconveni-ence. This invention, therefore, will be very useful to the development of language studies in Indonesia to develop the theory of pragmatics $(\mathrm{Yu}, 2011)$. This invention also has very clear practical implication, i.e. to enrich the more qualified teaching material of context un pragmatics. Teaching context of pragmatics to Indonesian students must not be merely conceptbased but should be research-result based 
(Bintari \& Sumarlam, 2019). By doing so, the develop-ment of students' pragmatic research competence will be pacing better and better in the future (R. Kunjana Rahardi, 2019).

\section{CONCLUSION}

From the results of the previous analysis and discussion, it can be concluded that the Javanese phatic word 'sampun' has several pragmatic mea-nings, namely (1) emphasizing intention, (2) em-phasizing the speaker's hope and expectation, (3) emphasizing the speaker's intention to convince the hearer, (4) emphasizing the speaker's inten-tion to question the hearer, (5) emphasizing the speaker's intention to agree, (6) conveying dis-appointment, (7) emphasizing the speaker's in-convenience. This research is still

\section{REFERENCES}

Anderson, B. (1972). The idea of power in Javanese culture: Culture and Politics in Indonesia. Cornell: Cornell University, https: //doi.org/10.1017/CBO9781107415324.004

Armstrong, E., \& Ferguson, A. (2010). Language, meaning, context, and functional communication. Aphasiology, 24(4), 480-496. https:// doi.org/10.1080/02687030902775157

Bintari, K., \& Sumarlam, S. (2019). Unsur pembentuk frasa eksosentris dalam hikayat Hang Tuah. Retorika: Jurnal Bahasa, Sastra, dan Penga-jarannya, 12(2), 154-164. https://doi.org/10. 26858/ retorika.v12i2.9468

Braten, E. (2001). Varieties of Javanese religion: An anthropological account varieties of Javanese religion. American Ethnologist, 28(4), 937-938, https://doi.org/doi:10.1525/ae.2001.28.4.937

Carston, R. (2005). Relevance theory, grice, and the neo-griceans: A response to Laurence Horn's "current issues in neo-Gricean pragmatics." Intercultural Pragmatics, 2(3), 303-319, https://doi.org/10. 1515/iprg.2005.2.3.303

Chen, J. (2017). Research trends in intercultural pragmatics. Australian Journal of Linguistics, 37(4), 530-533, https:// doi.org/10.1080/07268602.2016.1204903

Chen, R., \& Yang, D. (2010). Responding to compliments in Chinese: Has it changed? Journal of Pragmatics, 42(7), 1951-1963, https://doi.org/10.1016/j.pragma. 2009.12.006

Cogo, A., \& House, J. (2017). Intercultural pragmatics. In The Routledge Handbook of Pragmatics. London: Routledge, limited to the case of phatic word 'sampun' in Javanese society and culture, therefore it is recommended that other researchers continue doing similar cases in different cultures either using the same theoretical perspective or using different perspectives to ad-vance the on-going studies of general pragmatics and culturespecific pragmatics in Indonesia.

\section{ACKNOWLEDGEMENT}

This research work is supported by DRPM, Ministry of Research, Technology, and Higher Education, The Republic of Indonesia. The writer thanks for the continual financial supports given for nine consecutive years by this institution.

https://doi.org/10.4324/9781315668925

Culpeper, J. (2010). Historical sociopragmatics. In His-torical Pragmatics, 10(2), 153-160.

de Rycker, A., \& Ponnudurai, P. (2011). The effect of online reading on argumentative essay writing quality. GEMA Online Journal of Language Studies, 11(3), 147-162.

Geertz, C. (1957). Ritual and social change: A Javanese example. American Anthropologist, 59(1), 32-54, https://doi. org/10.1525/ aa.1957.59.1.02a00040

Goddard, C. (2004). The ethnopragmatics and semantics of "active metaphors." Journal of Pragmatics, 36(7), 1211-1230, https://doi.org/ 10.1016/j.pragma.2003.10.011

Halliday, M. A. K. (1978). Language as social semiotic: the social interpretation of language and mea-ning. American Anthropologist, New Series, 83(3), 659-661, https://doi.org/10.1525/aa.1981.83.3.02a00360

Halliday, M. A. K. (2015). Language as social semiotic. In Soziosemiotik. Grundlagentexte. https://doi. org/10.1016/0346-251X(81)90015-4

Herliana, E. T. (2015). Preserving Javanese culture through retail activities in pasar Beringharjo, Yogyakarta. Procedia - Social and Behavioral Sciences, 184, 206-213, https://doi.org/10.1016/j.sbspro. 2015. 05.081

Kotthoff, H. (2005). Gender and humor: The state of the art. Journal of Pragmatics, 38(1), 4-25, https://doi.org/10. 1016/j.pragma.2005.06.003

Kramsch, C.(2002). Language and culture: A social semiotic perspective. Adfl, 33(2), 8-15, 
https://doi.org/10. 1632/adfl.33.2.8

Kridalaksana, H. (1979). Lexicography in Indonesia. RELC Journal, 10(2), 57-66, https://doi.org/10.1177/003368827901000205

Lukens-bull, R. A. (1995). Teaching morality: Javanese Islamic education in a globalizing era 1. Journal of Arabic and Islamic Studies, 32(3), 350-372,

https://doi.org/10.1525/aeq.2001.32.3.350

Mey, J. L. (2002). Symbolic domination and postcolonial contestation: Resources and conditions. Journal of Pragmatics, 34(3), 285-330, https://doi.org/10.1016/ S0378-2166(02)800030

Mey, J. L. (2006). Focus-on issue: Intercultural pragmatics and sociolinguistics. Journal of Pragmatics, 38(11), 1793-1794, https://doi.org/ 10.1016/j.pragma.2006.07.002

Mey, J. L. L., Brown, K., \& Mey, J. L. L. (2006). Pragmatics: Overview. In Encyclodpedia of language and linguistics. https://doi.org/10. 1002/9781405198431.wbeal1338

Mills, S. (2009). Impoliteness in a cultural context. Journal of Pragmatics, 41(5), 1047-1060, https://doi.org/10.1016/ j.pragma.2008.10.014

Palacio, M. A., \& Gustilo, L. (2016). A pragmatic analysis of discourse particles in Filipino computer mediated communication. GEMA Online Journal of Language Studies, 16(3), 1-19, https://doi.org/10.17576/gema-2016-1603-01

Rahardi, R. Kunjana. (2010). Sosiopragmatik (1st ed.). Jakarta: Erlangga.

Rahardi, R. Kunjana. (2017a). Language Phatic in specific culture perspective. In 1st International Conference on Education, Language, and Arts (pp. 1165-1174). Jakarta: Universitas Negeri Jakarta.

Rahardi, R. K. (2017b). Linguistic impoliteness in the sociopragmatic perspective. Jurnal Humaniora, 29(3), https://doi.org/10.22146/jh.v29i3. 24954

Rahardi, R. K. (2017c). Pragmatic phenomena constellation in specific culture dimension language study. International Journal of Humanity Studies, 1(1), 84-92, https://doi.org/ doi.org/10.24071/ijhs.2017.010109

Rahardi, R. K. (2018a). Elemen dan fungsi konteks sosial, sosietal, dan situasional dalam menentukan makna pragmatik kefatisan berbahasa. In Prosiding Seminar Tahunan Linguistik Universitas Pendidikan Indonesia (SETALI 2018) (pp. 654-658). Bandung: Sekolah Pascasarjana Universitas Pendidikan Bandung.

Rahardi, R. K. 2018b. Pragmatik: Kefatisan berbahasa sebagai fenomena pragmatik baru dalam perspektif sosiokultural dan situasional (1st ed.). Jakarta: Erlangga.

Rahardi, R K. (2018c). Phatic language in a specific culture perspective in the context of internationalization of the Indonesian language. $K n E$ Social Sciences. https://doi.org/10.18502/kss. v3i9.2720

Rahardi, R. Kunjana. (2019). Pragmatic perspective on phatic functions and language dignity. International Journal of Engineering and Advanced Technology, 8(5C, May 2019), 261268, http://10.35940/ijeat.E1039. 0585C19

Rashid, R. A., Ismail, I. R., Ismail, R., \& Mamat, R. (2017). Ketidaksantunan dalam Perbualan Bahasa Jepun oleh Pemandu Pelancong Malaysia. GEMA Online Journal of Language Studies, 17(3), 86-105, https://doi.org/ 10.17576/gema-2017-1703-06

Renkema, J. (2005). Introduction to discourse studies. pragmatics, 38(12), 2238-2241, https://doi.org/ 10.1016/j.pragma. 2006.06.001

Robbins, J. (2008). Introduction: Cultural and linguistic anthropology and the opacity of other minds. Anthropological Quarterly, 81(2), 407420, https://doi.org/10. 1353/anq.0.0005

Salehuddin, K., Winskel, H., \& Maros, M. (2011). The pragmatic functions of numeral classifiers in modern Malay written corpus. GEMA Online Journal of Language Studies, 11(2), 137-153.

Sarsito, T. (2006). Javanese culture as the source of legitimacy for Soeharto's government. Asia Europe Journal, 4(3), 447-461, https://doi.org/10.1007/s10308-006-00 78-y

Scollon, R., \& Scollon, S. W. (2001). Intercultural communication: A discurse approach. Sociolinguistics, 7(9), 1565-1572, https://doi. org/10.1128/EC.00123-08

Spencer-Oatey, H., \& Jiang, W. (2003). Explaining cross-cultural pragmatic findings: Moving from politeness maxims to sociopragmatic interactional principles (SIPs). Journal of Pragmatics, 35(10-11), 1633-1650, https://doi.org/10.1016/ $-2166(03) 00025-0$

Sudaryanto. (2015). Metode dan aneka teknik analisis bahasa: Pengantar penelitian wahana kebudayaan secara linguistis (1st ed.). Yogyakarta: Sanata Dharma University Press.

Waugh, L. R., Catalano, T., Al Masaeed, K., Do, T. H., \& Renigar, P. G. (2016). Critical discourse analysis: Definition, approaches, relation to pragmatics, critique, and trends. In Perspectives in Pragmatics, Philosophy and Psychology, 4, 71-135, https:// doi.org/10.1007/978-3-319$12616-6 \_4$

Wharton, T. (2009). Pragmatics and non-verbal communication. London: Cambridge University Press., https://doi.org/10.1017/CBO97805 11635649

Wiley, R. H. (1983). The evolution of communication: Information and manipulation. Communication, 2(2), 156-189. 
Wodak, R., \& Meyer, M. (2016). Critical discourse studies: History, agenda, theory and methodology. In Methods of critical discourse studies, 52(83),194-191, https://doi.org/10.1016/S03767361(09)70018-4

Wodak, R. (2007). Pragmatics and critical discourse analysis. Pragmatics \& Cognition, 4(2), 249-
283, https://doi. org/10.1177/0957926593004002006

Yu, K. A. (2011). Culture-specific concepts of politeness: Indirectness and politeness in English, Hebrew, and Korean requests. Intercultural Pragmatics, 8(3), 385-409, https://doi.org/10. 1515/IPRG. 2011. 018 